\title{
BETWEEN DISTANCE AND SYMPATHY: DR JOHN MOORE'S PHILOSOPHICAL TRAVEL WRITING
}

\section{JOHN BREWER}

Division of Humanities and Social Sciences, California Institute of Technology E-mail: jbcaltech@yahoo.com

Dr John Moore's four-volume account of his Grand Tour in the company of the Duke of Hamilton was one of the most successful European travel books of the late eighteenth century. Moore's text, I argue, is a philosophical travel narrative, an examination of manners, customs and characters, analogous to the philosophical histories of the Scottish Enlightenment. Intended as a critique of the superficial observations of much travel literature, it argues for a greater degree of closeness between the traveler and the native, one based on sympathetic conversation rather than observation, but accompanied by a more distanced analysis, based on conjectural history, of the hidden processes that explain manners and character. Difference should be understood through a combination of sympathy and analysis that makes travel and its accounting valuable.

The last quarter of the eighteenth century saw the growth of what was already a flourishing literary genre, the travel narrative, as European authors regaled their readers with accounts of journeys into the Pacific and Australasia, the Americas, Africa, and the Middle and Far East. The attraction of such accounts largely stemmed from their novelty, the way they conveyed a sense of discovery and wonder. Compared with such exotic (and often questioned) tales, the ongoing packaging and publication of European travel may have come to seem humdrum, treading well-worn paths, enumerating familiar sites and reiterating routine experiences. ${ }^{1}$ Nevertheless, recent scholarly literature on European travel, and especially writings on the Grand Tour, has mimicked the critical concerns of those examining the European encounter with non-European "others". In both

Thus Richard Hurd in his Dialogues on Travel (London, 1767), 158: "The tour of Europe is, a paltry thing: a tame, uniform, unvaried prospect; which affords nothing but the same polished manners and artificial policies, scarcely diversified enough to take, or merit our

- attention ... It is from a wider and more extensive view of mankind that a just estimate is to be made of the powers of human nature" (original emphasis). 
cases, in a field where scholars have tried to move beyond, but have been unable to forget Edward Said's Orientalism, much eighteenth- and nineteenth-century travel writing is treated as premised on a binary distinction between civilized and savage, developed and undeveloped, and peoples with or without history. In this literature the position of the observer, no matter how sympathetic to the observed, is trapped into performing what Arjan Appadurai has memorably described as "metonymic freezing".

Though much of value has been learned by such an approach, it can have the effect of flattening out, of making too one-dimensional the extremely complex relationships between the writer and his or her subject. One of the benefits of employing an analysis of travel writing explicitly built around notions of closeness and distance, especially in their nuanced forms elaborated in Mark Salber Phillips's work, is that it necessarily complicates the relationship between author and "other", by requiring us, even when we recognize the (sometimes brutal) asymmetries of power that have preoccupied post-Saidian scholarship, to examine the very various techniques by which differences and similarities were conceptualized and understood. Difference becomes a starting point, not an end.

In the case of the Scottish enlightenment, histories, rather than travel literature, have been the focus of such studies, but in this essay I want to consider one of the most popular works of European travels published in the last quarter of the eighteenth century, a four-volume, two-title account of what was a single journey, the Grand Tour of the young 8th Duke of Hamilton, as described by his doctor, tutor and friend, Dr John Moore. In his A View of Society and Manners in France, Germany and Switzerland (2 vols., 1779), and his companion volumes published two years later, A View of Society and Manners in Italy (2 vols., 1781), Moore, I argue, not only sought to inject into such travel books the sort of historical analysis we associate with David Hume, John Millar (a close friend of Moore's), and Adam Smith, but also used Smithian notions of sympathy, to propound a distinctive way of understanding the value of travel and the aims of travel writing.

John Moore was born in 1729, the son of a moderate Presbyterian minister, and the cousin and friend of the novelist Tobias Smollett (whose biography he wrote in the 179os, but whose politics he did not share). He was apprenticed as a surgeon, and then educated at Glasgow University, where he studied with William Cullen, the charismatic teacher of Enlightenment neuropathology, and attended the lectures of the philosopher Francis Hutcheson, whose work remained a lifelong influence. After service as a military surgeon, he studied anatomy in London with William Hunter (another of Cullen's protégés) and midwifery with William Smellie; he also spent some time in Paris studying surgery and children's 
medicine, while serving as surgeon to the British ambassador. (He became a fluent French speaker and a lifelong Francophile.) Between 1750 and 1772 he was back in Scotland, chiefly in Glasgow where he became a close friend of the professor of civil law and author of Observations concerning the Distinction of Ranks in Society, John Millar, and was an active figure in the city's club life and literary circles. In 1769 he was recommended by William Cullen to Elizabeth Gunning, Duchess of Argyll, and after the premature death of her son, the 7 th Duke of Hamilton, she engaged Moore to act as the tutor, companion and doctor to the new (8th) Duke of Hamilton on a grand tour of Europe that took the two men, together with Moore's son John, ${ }^{3}$ through France, Germany, Switzerland and Italy, a journey that lasted nearly five years, between 1772 and 1777 . On his return Moore moved to London and became a literary figure, publishing his travel books, novels and medical treatises, and moving among liberal and reformist circles. He traveled to Paris in 1792 with the Foxite peer and political economist Lord Lauderdale, and subsequently published a two-volume analysis of events in France entitled View on the Causes and Progress of the French Revolution. ${ }^{4}$

Moore's moderate Presbyterian upbringing, his education at Glasgow University, his place at the heart of Enlightenment medicine, his friendships with major Enlightenment figures in Glasgow and Edinburgh and with Whigs and radicals in London, reveal him to have been a typical figure of the Scottish Enlightenment whose views were strongly inflected by moral philosophy, current medical theory, and the developmental theories and conjectural history of the likes of Millar and Smith. Like those of many doctors of the Scottish Enlightenment, his interests were never confined to medicine. His travel literature and three novels (the best-selling Zeluco (1789), Edward (1796), and Mordaunt (1800)) were all concerned with his lifelong interest in human nature and the processes by which manners and morals were shaped.

Moore's four-volume account of his journeys with the Duke of Hamilton ran to about two thousand pages, but nevertheless proved a remarkable bestseller., A View of Society and Manners in France ran through nine London editions between 1779 and Moore's death in 1802; there were also six Dublin and two American editions, as well as translations into French, German and Italian. The subsequent volumes, $A$ View of Society and Manners in Italy, went through six London editions between 1781 and 1795, four Dublin editions, and imprints in Boston and Philadelphia. To put this in perspective, Hester Piozzi's Observations and Reflections made in the course of a journey through France, Italy and Germany

John Moore, who later became a distinguished soldier, achieved posthumous fame as Moore of Corunna.

4 For Moore's life see DNB; European Magazine and London Review, 17 (1790), Frontispiece, 5-6. 
appeared only in single London and Dublin editions in 1789, as well as a German translation published in Frankfurt am Main a year later. Moore's cousin and fellow doctor, Tobias Smollett, despite his considerable literary fame, only sold three London and two Dublin editions of his Travels in France and Italy published in 1766. The one European travel book in English published in the second half of the century (excepting Laurence Sterne's idiosyncratic Sentimental Journey) that enjoyed comparable success was Patrick Brydone's $A$ Tour through Sicily and Malta: in a series of letters to William Beckford, esq. of Somerly in Suffolk (2 vols., 1773), a work of considerable literary accomplishment that also revealed a region of Europe that was largely unknown to British readers. ${ }^{5}$

When Moore published his Views, European travel writing was in a state of flux. ${ }^{6}$ Prompted in part by a certain weariness with hackneyed accounts of familiar places, travel narratives began to adopt new authorial strategies: some gave greater emphasis to the feelings and sentiments of the narrator; others expanded their comments or reflections to analyse the customs and manners of the people they encountered on their travels; many paid renewed attention to landscape and scenery and the emotions they engendered. All three approaches can, in their different ways, be characterized as concerned with feeling and sentiment, though as we shall see, they operated in different idioms.

From the very outset Moore makes clear that he intends his View as a study of "Manners, customs and characters" rather than of palaces and churches, which "generally afford but a slender entertainment when served up in description"? All his volumes are remarkably inattentive to the logistics of travel. They contain no practical information of the sort included in Thomas Martyn's Gentleman's Guide in his Tour through Italy (1787), with its information about routes, exchange rates and posts, a format that was becoming more and more common in the last quarter of the century. They rarely enumerate in any consistent or precise way "sites" that should be viewed and noted, often trailing off or ending a list of items with a perfunctory remark about it being unnecessary, either because of their familiarity or because a description was easily available in other printed sources. Describing the new Neapolitan royal palace at Caserta, for example, he interpolates, "But I have a notion you are tired of this description, which I assure

5 Brydone editions: eleven in London .1773-1807; four Dublin editions; Edinburgh, Perth; Amsterdam, Leipzig, Paris, Turin; New York, Boston, Philadelphia, Greenfield, MA. These and other publication figures are assembled from the catalogues, on the British Library, the Bodleian Library, the Harvard Libraries and the Huntington Library, and from ECCO.

6 Charles L. Batten, Pleasurable Instruction: Form and Convention in Eighteenth-Century Travel Literature (Berkeley, 1978), esp. 77-80, 91-4.

7 View of Society and Manners in France, Germany and Switzerland, 2 vols. (hereafter VSMF) (London, 1779), 1: 12-13. 
you is likewise in my case". Description, or perhaps more aptly. observation, is subordinate to reflection. Moore chooses to emphasize particular phenomena as part of a broader analysis of customs and manners.

His, then, is a partial view, but it is not like those of so many imitators of Sterne's Sentimental Journey, one in which the author's feelings constantly intrude upon the narrative. Indeed, Moore conveys very little sense of his tour as an exercise in self-understanding or as an exploration of personal feeling. The object of understanding is external-the society and manners of Europe's nations-and, as we shall see, the means by which Moore wishes to secure this is through a combination of careful observation and sympathetic appraisal, tempered by notions of justice.

Of course, there was much that was quite conventional in Moore's account. The route that he and the Duke of Hamilton followed was that of the customary Grand Tour: to Paris, and then to the south of France, the Alps and the Swiss cantons (taking in the mandatory visit to Voltaire at Ferney); a journey through the small courts of Germany to Berlin and Austria; and, finally, the trip southwards into Italy and the classical Grand Tour. Moore could hardly avoid the conventional requirement of the travel writer "to describe the various objects that successively present themselves to his view, to communicate anecdotes of the company he is introduced into, and to relate incidental occurrences that offer themselves to his notice." Indeed, it is clear from the reviewers that much of the attraction of the View was its lively, conversational style, its frequent digressions, and its amusing anecdotes. But, as his narrative proceeded, Moore's emphasis slowly shifted. Despite certain similarities-a concern with political and religious arrangements, an emphasis on national character, and a disquiet about what it was that a young man might learn through travel - the optic of the French, Swiss and German View is different from that taken in the later Italian volumes. Moore's northern European perspective is more up-close, its temporality more in the present, making his story, as he himself concedes, "anecdotal". The Italian account is also not without its amusing asides, but regularly pulls back from the immediate circumstances of the tour, offering its readers more general reflections on Italy, its culture and its inhabitants. Society in the early volumes seems to be used most often in its restricted sense of "those who count", which usually means the nobility and, especially in Germany, members of the court. In Italy, however, and despite visits to a number of courts-in Turin, Florence, Rome and NaplesMoore's vision is more panoramic as well as analytic. Society extends beyond the sphere of the polite. It is unclear why this shift occurred. It may be that 304. 
Moore was more interested in the larger questions that classical and Italian civilizations posed, or that he pursued the Italian case more broadly-as well as in greater depth-because of the controversies of the previous decade, notably the rather fierce debate between the physician Samuel Sharp and the Italian friend of Dr Johnson, Guiseppe Marc'Antonio Baretti. Italy was also the focus of "the north/south debate" on the causes of industry and commercial success in northern Europe and the lassitude and backwardness of the Mediterranean, a question that had divided Hume and Montesquieu, and about which Moore had pronounced (pro-Humean) views.

Throughout the volumes, Moore combines comedy, irony and analysis, though the last category becomes increasingly important during the Italian tour. His sources of inspiration are his relative and fellow doctor, Tobias Smollett; Lawrence Sterne's Sentimental Journey (with the irony but without the solipsism and gentle eroticism); and Adam Smith and his followers, combining the Smith both of The Theory of Moral Sentiments and of The Wealth of Nations, which Moore cites explicitly in his text. The tenor of Moore's account is, as we shall see, not merely a question of style, but also a position about the proper feelings of the philosophical traveler.

Moore reserves the comic for the narrative passages about the journey with his young charge, for the personal anecdotes and random incidents that are the inevitable but particular accompaniment of travel, and which writers like Smollett made increasingly popular in the travel literature of the second half of the century. One of Moore's funniest (yet most shrewdly told) stories is his hilarious account of the young Duke of Hamilton's anger when, having worked to secure a visit to the Pope, he learns that he has been thwarted by a papal official from kissing the Holy Father's toe. ${ }^{10}$ The priest fears that the young Protestant gentleman will be insulted by being asked for such a gesture of obeisance. Moore neatly captures the petulant young noble's feelings: having gone to such lengths to secure an audience, the very least he expected was a moment of intimate contact. The story could have come straight out of Smollett's The History and Adventures of an Atom (1769), a novel that also featured a ruler's toe. It is told in a way that establishes both distance and complicity: we laugh at the duke's perplexity but we share in Moore's amusement, even when, as in other incidents, his anecdotes are at his own expense.

Moore's text uses irony in two rather different contexts. The first mocks the behavior and attitudes of travelers who, in Moore's view, fail, though pomposity, narrow-minded chauvinism, or enthusiasm, to learn from their travels. In Paris he tells the story of his English friend " $B$ ", whose blind antipathy 
to the French construes every act of hospitality and politeness as evidence of French duplicity and insincerity. Throughout his text, he takes connoisseurs to task for their doctrinaire attitudes towards works of art and antiquity; their insistence on a private, technical attitude to works of art; and their contempt for untutored observers. This is partly a personal response: as he makes clear, he lacks the sensibility of a connoisseur because "I have felt more compassion at the sight of a single highwayman going to Tyburn, than at the massacre of two thousand innocents, though executed by Nicholas Poussin himself"." But he also regarded connoisseurial judgement as a form of arrogance that inhibits appreciation and understanding. He regales the reader with stories of arrogant misattributions, complains that squabbling connoisseurs interfere with his pleasure in contemplating ancient sculpture, and explains that true art appreciation comes from the heart rather than technical knowledge, from sympathy rather than treatises. ${ }^{12}$ As he says of a Madonna by Guido Reni, "It requires no knowledge in the art of painting, no connoisseurship, to discover those beauties in the works of Guido; all who have eyes, and a heart, must see and feel them". ${ }^{13}$ His response to the antiquities of Rome (and he always had much more interest in antiquity than in more recent art) was highly emotive. Admiring the statue of Niobe in the Villa Medici in Rome, he writes,

The author of the Niobe has had the judgment not to exhibit all the distress which he might have placed in her countenance. This consummate artist was afraid of disturbing her features too much, knowing full well, that the point where he was to expect the most sympathy was there, where distress co-operated with beauty, and where our pity met our love. ${ }^{4}$

Moore makes clear that the way to appreciate art, like the way to learn from travel, is through sympathy.

Moore's irony is not just reserved for the traveler, but is similarly deployed to chide the unnatural punctilio of courts, and the enthusiasm and superstition of religious zealots. He repeatedly satirizes the rigid etiquette and exaggerated ceremony of the small German courts, not so much as an expression of absolutism (for the absolutist courts of Berlin and Vienna lack this formality), but as creating a system of manners that inhibits conversation and understanding. ${ }^{15}$ Religious enthusiasm and superstition provoke Moore's irony rather than forthright condemnation: he remarks of one monk's holy relics, known for their sweet

\footnotetext{
$11 \quad$ Ibid., 1: 63.

12 Ibid., 1: 63, 359, 361; 2: 3-4, 427, 430.

13 Ibid., 1: 311.

14 Ibid., 1: 500, original emphasis.

15 E.g. VSMF, 1: 390.
} 
odor, that they smelt far better than any living Franciscan, and he plays up the miracle of the angelic transportation of the Holy House of Joseph and Maryfirst to Croatia and then Loretto-by commenting credulously on the fortunate availability of Italian brick to build a dwelling in the Holy Land. ${ }^{16}$ His remarks are not just-directed at the Catholic Church; he also has a droll account of the antics of a crazed Scottish Presbyterian who had come to Rome to convert Antichrist and who was kindly received by Pope Clement XIV. ${ }^{17}$ In both cases Moore satirizes what he sees as a deviation from true Christianity. As he remarks, "happy for Christians of every denomination, could they abide by the plain, rational, benevolent precepts of the Christian religion, rejecting all the conceits of superstition, which never fail to deform its original beauty, and to corrupt its intrinsic purity!" ${ }^{\prime 2}$

Moore's storytelling skills and his tart irony made for good reading, but his manner was more than a matter of literary artifice. It positioned both the author and the reader in a particular relation to the foreign, one that might register disagreement or difference, but which avoided sententious moralizing and outright condemnation. The aim was to establish the position of the impartial but sympathetic narrator. In fact, Moore's most stringent and outspoken criticisms are addressed far more to the ways in which the experiences of travel are understood, and much less to the practices and customs of the foreign itself.

Thus Moore's account of his travels repeatedly reflects on the purposes of travel and the proper posture of the traveler towards his hosts. He insists that a true understanding of other cultures entails much more than superficial observation. "To form a proper judgment of the genius and manners of any nation, it is necessary to live familiarly with the inhabitants for a considerable time." ${ }^{19} \mathrm{He}$ encourages travelers to sit down at the table d'hotte of an inn rather than confine their knowledge to courts, and he repeatedly condemns the notorious practice of British travelers who herd together and avoid foreigners: "they confirm each other in all their prejudices, and with united voice condemn and ridicule the customs and manners of every country but their own". ${ }^{20}$ He urges the study of foreign languages, not just to give access to other literatures, but to enable travelers to converse on the road. His text is full of exemplars of these injunctions, including frequent conversations, such as the debate with a Prussian army officer about the extent of cruelty in the Prussian army. Moore makes his own views clear, but he also lays out the countercase put by the officer, whose views are reported in

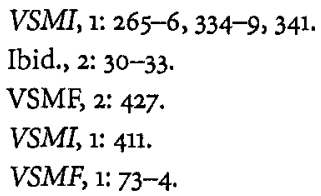


direct speech. ${ }^{21}$ There is no question here of ventriloquizing "the other"; rather the voice of the foreign is used to unfold the complexity of issues, but also to encourage sympathy and understanding. Moore repeatedly makes clear that he believes that knowledge and understanding come about through conversation, through direct, close mental proximity. Moore's model of engagement, then, is not primarily visual - travel is not just a matter of an active spectator looking at people and things as passive objects of observation-hence, perhaps, his hostility to the connoisseur. Rather, the purpose of travel, a proper understanding of the other, is realized through the shared process of verbal exchange.

The direct experience of travel is therefore vital, but it is also not enough. The traveler has to have the ability to understand his interactions with strangers and the foreign, and for this he needs to comprehend the processes of history, and the ways in which manners and characters come to be formed. The traveler has to move beyond surface appearances. Thus in his account of Venice, Moore devotes only a few pages to the usual objects of tourism-the works of Titian, Tintoretto, Veronese and the Venetian school of painters-but writes at great length (about 170 pages) about the relationship between war and commerce, and the evolution of political institutions in the history of the city, which, like other commentators, he regarded as increasingly autocratic. ${ }^{22}$ At the end of his account he explains that his object has been to prevent readers from "being in the situation of some travelers I have met with, who, after remaining here for many months, knew no more of the ancient and modern state of Venice, than that the inhabitants went about in boats instead of coaches, and, generally speaking, wore masks." ${ }^{23}$ Paradoxically, then, the process of standing back from immediate experience, which might seem a form of distancing, brings the traveler closer to his object.

Moore's position is very like that of the clerical political economist, Josiah Tucker, in his Instructions for Travellers, originally privately printed but then published in 1758. Tucker recognizes many different sorts of traveler, including those in pursuit of collections for natural philosophy or the fine arts; those seeking to acquire taste and virtu, or wanting to learn foreign manners and fashions; and (more laudably) those trying to dispel local prejudices, or to appreciate classical civilization. But all, he says, should subordinate these interests to a more important aim. The modern traveler

should constantly bear in mind the grand Maxim, That the face of every Country through which he passes, the Looks, Numbers, and Behaviour of the People, their general Clothing,

\footnotetext{
21 Ibid., 2: 156 et seq., 207.

22 VSMI, 1: 54, 39-214.

23 Ibid., 1: 214.
} 
Food, and Dwelling, their attainments in Agriculture, Manufactures, Arts and Sciences, are the Effects and Consequences of some certain Causes. ${ }^{24}$

It is only through an examination of these many different aspects of a nation that it is possible to understand how it comes to be as it is.

The requirement for such a broad range of information made considerable demands on the traveler, ones that some travel writers had long tried to fulfill. Moore, for example, drew on Johann Georg Keyssler's Travels through Germany, Bohemia, Hungary, Switzerland, Italy and Lorraine, which appeared in English in the same year as Tucker's Essay, for information about different nations' "Natural, Literary, and Political History; Manners, Laws, Commerce, Manufactures, Painting, Sculpture, Architecture, Coins, Antiquities, Curiosities of Art and Nature". But the demand made from the mid-century was for more than an inventory of characteristics; it called for a causal explanation. The traveler, says Tucker, "must dedicate his principal studies towards tracing such secret, though powerful Effects and Consequences, as they are produced by the various Systems of Religion, Government, and Commerce in the World". He needs to learn

whether and how far the said Effects may be ascribed to the natural Soil and Situation of the Country.-To the peculiar Genius and singular Inventions of the Inhabitants.-To the Public Spirit and Tenor of their Constitution,- - or to the Religious Principles established, or tolerated among them. ${ }^{25}$

Moore's response to the sort of challenge posed by Tucker and others was not to beef up the quantity and enhance the character of travel information, but to frame his narrative as a study of "manners and society". In this he was following a fashion in travel writing, but he was also at pains to deviate from it. For many authors, accounts of foreign manners and customs were the occasion for dressing up a number of long-standing prejudices, especially about Catholicism and absolutism, in modern clothing. Typical of this literature was the physician Samuel Sharp's popular and inflammatory Letters from Italy, describing the customs and manners of that country, in the years 1765 and 1766, which was filled with clichés about Catholic superstition, autocratic repression, and the deleterious effects of the absence of liberty, and which condemned Italians, at a stroke, as perfidious, crafty and treacherous. ${ }^{26}$ As Moore knew, Sharp had put into print what numerous British travelers on the Continent, especially in Italy, expressed repeatedly in their journals and letters. As such writers acknowledged,

Josiah Tucker, Instructions for Travellers (Dublin, 1758), 15.

Ibid., 15.

Samuel Sharp, Letters from Italy, describing the customs and manners of that country, in the years 1765 and 1766 , to which is annexed an admonition to Gentlemen who pass the Alps in their Tour through Italy (London, 1767). 
their work was designed to show "under what a dreadful yoke the wretched people of other nations groan, their more than Egyptian task-masters having impiously robbed them of the use of that glorious faculty, their reason, deprived them of their properties, and all this under the sacred sanction of religion". ${ }^{27}$ This, very clearly was a literature of "otherness", designed to demonstrate the. differences and inferiority of other peoples and nations, and to construe travel as a means of reinforcing (a narrow-minded) patriotism. Often it was accompanied by warnings of the dire consequences of acquiring the habits and manners of foreigners.

This was the version of customs, manners and character that Moore set out to rebut. Not that Moore was the advocate of an aristocratic cosmopolitanism, nor did he deny the value of a certain sort of love of country, which he regarded as almost inevitable. Indeed, he went to some lengths to emphasize the importance for British travelers of a proper British education (completed before the beginnings of travel), and, in one of his long digressions on whether it was better for a young Englishman (less than ten years old) to be educated at home or abroad, argued that it was best that a young English noble be educated in England:

The most important point, in my mind, to be secured in the education of a young man of rank in our country, is to make him an Englishman; and this can be done nowhere so effectually as in England.

He will there acquire those sentiments, that particular taste and turn of mind, which will make him prefer the government, and relish the manner, the diversion, and general way of living, which prevail in England ...

He will there acquire that character, which distinguishes Englishmen from the natives of all the other countries of Europe, and which once attained, however it may be afterwards embellished or deformed, can never be entirely effaced.

If it could be proved, that this character is not the most amiable, it does not follow that it is not the most expedient. It is sufficient, that it is upon the whole most approved of in England. For I hold it as indisputable, that the good opinion of a man's countrymen is of more importance to him than that of the rest of mankind: Indeed, without the first he can rarely enjoy the other. ${ }^{28}$

Sacheverell Stevens, Miscellaneous Remarks Made on the Spot in a late Seven Years Tour through France, Italy, Germany and Holland (n.d., London), dedication.

28

VSMF, 1: 287-8. Moore here seems to be responding to the debate in Hurd's Dialogues on Travel, in which the virtues of domestic versus foreign education, and the question of the best age at which young men should travel, are rehearsed between "Locke" and "Shaftesbury". Moore refers explicitly to Hurd's Dialogues, but on the whole his travel account is not directed to the question of the education of young aristocrats but to a more 
Notably, Moore argues pragmatically rather than morally in favour of a native education. British national character is best made in Britain; to live in Britain, be a British noble and acquire a foreign character is to invite opprobrium and misfortune. Foreign education for a mature Englishman had many benefits, but not for an unformed youth.

In these views Moore, like many of his contemporaries, including, most famously, David Hume, reveals a preoccupation with the issue of national character. Moore's View shares with Hume the assumptions that, as the philosopher put it, "each nation has a peculiar set of manners, and that some particular qualities are more frequently to be met with among one people than among their neighbours". ${ }^{29}$ Indeed the opening pages of the first volume of A View of Society and Manners in France are devoted to an account of the French national character, one in which a general diffusion of "politeness and good manners", together with a peculiar attachment to monarchy and privilege, feature prominently. ${ }^{30}$ But, again like Hume; Moore does not treat the notion of national character rigidly; he endorses Hume's view that it is an error "to carry all national characters to extremes; and having once established it as a principle, that any people are knavish, or cowardly, or ignorant ... [to] admit of no exception, but comprehend every individual under the same censure."31 Thus, after Moore identifies the general dissemination of "politeness and good manners" as a "remarkable and distinguishing feature of the French national character", he quickly adds, "there are exceptions to those, as to all general remarks on the manners and character of any nation. "32 Indeed, Moore positively revels in the complexity of national manners and customs, and delights in cases that seem to subvert national clichés. He is deeply intrigued by the Catholic Swiss cantons because, counterintuitively, they are more democratic and less aristocratic than their Protestant counterparts. ${ }^{33} \mathrm{He}$ is engagingly surprised to discover that Berlin has a free press, openly critical of Frederick the Great. ${ }^{34}$ Though he mocks the superstition of the Italian Catholic church, he praises the ecclesiastical authorities as caring paternalist landlords when compared with the southern aristocracy. ${ }^{35}$ And he persistently draws a distinction between what we

general understanding of the purposes of travel, though he does return to the topic in the final pages of VSMI (2: esp. 494-7).

David Hume, Essays, Moral, Political and Literary, ed. Eugene F. Miller (Indianapolis, 1987), 197.

30 VSMF, 1: 28-9.

${ }^{31}$ Hume, Essays, 197, original emphasis.

32 , VSMF, 1: 29.

33 Ibid., 1: 335-6.

34 Ibid., 2: 187.

35 VSMI, 1: 384 . 
might think of as structural constraints and expectations and contingent and personal circumstances that change outcomes. French tyranny is moderated but not removed by French politesse; the Margrave of Baden is a fair ruler but this does not mean that his subjects enjoy any rights. ${ }^{36}$

Moore sees many customs and manners as contingent, the result of what Hume referred to as "accidents", but also points out that many customs, though they may at first sight appear strange, also have local utility:

When an acute sensible people universally follow one custom, in a mere matter of conveniency, however absurd that custom may appear in the eyes of the stranger at first sight, it will generally be found, that there is some real advantage in it, which compensates all the apparent inconveniencies. ${ }^{37}$

It may seem odd to an Englishmen to put the piano nobile on the second rather than the first floor, but is wise in wet and damp Venice. ${ }^{38}$ The showiness of Neapolitan aristocrats makes sense in the court-dominated society of an absolutist state, but not in a polity like Britain. ${ }^{39}$ And where utility does not operate, manners become a matter of fashion, a question of local custom and predilection.

Even the strangest customs lend themselves to understanding. Moore, for instance, discusses two Italian examples in depth: murder by stabbing-the use of the stiletto-and the practice of cicisbeanism, of married women appearing in public escorted by regular male companions (the cicisbeo) who were not their husbands. ${ }^{40}$ Both of these practices were seen by many British commentators as clear markers, distinguishing British willingness to fight openly from Italian duplicity, and the English commitment to companionate marriage from Italian predilections for sexual intrigue: British candor contrasted with Italian deceit. On the first, Moore concedes that it is a common opinion among travelers that Italians are. "deceitful, perfidious and vengeful; and [that] the frequent assassinations and murders which happen in the streets of the great towns of Italy, are brought as proofs of this charge".41 But he explains the phenomenon not as a matter of "national character" as such, which, he does not view as fixed,

\footnotetext{
VSMF, 1: 385.

VSMI, 1: 252-3.

Ibid., $1: 252$.

Ibid., 2: 259.
}

40 On Cicisbeanism in general see Roberto Bizzocchi, "Cicisbei: Italian morality and European values in the Eighteenth Century", in Paula Findlen, Wendy Wassyng Roworth and Catherine M. Sama, eds., Italy's Eighteenth Century: Gender and Culture in the Age of the Grand Tour (Stanford, 2009), 35-58; Chloe Chard, Pleasure and Guilt on the Grand Tour (Manchester, 1999), 91-3, 128-30, 237-8. 
but as a consequence of the distrust and contempt with which most police are viewed, the ease with which offenders can avoid prosecution, and the frequency with which they could seek refuge in a church or convent. "As soon as asylums for such criminals are abolished", he asserts, "and justice is allowed to take its natural course, that foul stain will be entirely effaced from the national character of modern Italians", and he cites as proof of his claim the decline of these crimes in Tuscany, where such reforms had recently been implemented. ${ }^{\mathbf{2}}$

Most commentators explained the presence of the cicisbeo by criticizing the treatment of Italian women: when unmarried they were confined and not allowed into society; once married off without their consent, and in reaction to their excessive constraint, they acted with excessive license. As the Welsh cleric Thomas Watkins put it, "Before marriage their women are nuns, and after it libertines." But Moore's explanation of a phenomenon that is, as he is at pains to point out, "unknown to the middle and lower ranks", 43 is all about the position of the upper classes in Italian society. ${ }^{44}$ (In general Moore shows an acute attention to these issues of social distinction, endorsing a Humean notion that particular occupations shape particular manners.) In "despotic states ... where it is dangerous to speak or write on general politics ... love becomes a first, instead of a secondary object ... and on this account women are the objects of greater attention and respect in despotic than in free countries". This may surprise the British traveler, Moore comments ironically, but they should recall that

the Italian nobility dare not intermeddle in politics; can find no employment in the army and navy; and that there are no such amusements in the country as hunting and drinking ... Even an Englishman, in those desperate circumstances, might be driven to the company and conversation of women, to lighten the burden of time.45

Moore also follows Hume (and other Scottish critics of Montesquieu such as his friend John Millar) in rejecting what they both called "physical" (i.e. climatological) causes for manners and character, endorsing Hume's remark that: "[a]s to physical causes, I am inclined to doubt altogether of their operation in this particular; nor do I think, that men owe any thing of their temper or genius to the air, food, or climate." Thus, in a discussion of British ennui, Moore rejects his French friend's explanation of the climate, pointing to "the excessive wealth of certain individuals and the state of society in our capital" as "the sole causes of our

42 Ibid., 1: 472 . More than a generation later Samuel Rogers made the same point in his best-selling poem Italy (London, 1838), 159.

43 Ibid., 2: 418.

44 The entire discussion is at Ibid., 2: 408-20.

45 Ibid., 2: 416. 
having a greater share of that malady among us than our neighbours". Clinching his argument with one of his typical moves he reminds us that "the common people of England know nothing of it [ennui]:- -neither do the industrious of any rank", though they share the same clime as the upper classes. ${ }^{46}$

But it is in his discussions of Italy rather than Britain that Moore makes most explicit his determination to explain differences in manners and character in terms of the effects of prevailing political and economic arrangements on a universal human nature. Here, of course, Moore was intervening in the debate, between David Hume and Baron de Montesquieu that had prompted the former's essay on national character. Many commentators on the narratives of the Grand Tour-including Chloe Chard, Melissa Calaresu, Joseph Luzzi and Nelson Moehave emphasized the fundamental importance of the distinction-most fully developed by and most commonly associated with Montesquieu-between a northern Europe whose inhabitants were characterized by austerity and industry and a southern Europe whose peoples were indolent. ${ }^{47}$ In De l'esprit des lois (1747) Montesquieu wrote,

There is a kind of balance between the southern and the northern nations. The first have every convenience of life, and few of its wants: the last have many wants, and few conveniences. To one nature has given much, and demands but a little; to the others, she has given but little, and demands a great deal. The equilibrium is maintained by the laziness [paresse] of the southern nations, and by the industry and activity which she has given to those in the north. The latter are obliged to undergo excessive labour, without which they would want every thing, and degenerate into barbarians. This has naturalized slavery to the people of the south, as they can easily dispense with riches, they can more easily dispense with liberty.

For many of those travelers who followed in the footsteps of Montesquieu (who was in Italy in 1729), climate, though not the only variable, was the key. Thus Joseph-Jerome Lefrancais de Lalande, in his popular guide Voyage d'un Francois en Italie (1769), writes of Naples, "This city has been nicknamed Otiosa, because the effect of the climate, the fertility of the soil, and the indifference of the government have always contributed to making the Neapolitans indolent."

As Naples became a more popular tourist destination in the second half of the eighteenth century, this view of the south was increasingly associated with the

46 VSMF, 2: 322-3.

47 Chard, Pleasure and Guilt, Joseph Luzzi, "Italy without Italians: Literary Origins of a Romantic Myth", Modern Language Notes, 117 (2002), 48-83; Nelson Moe, The View from Vesuvius: Italian Culture and the Southern Question (Berkeley, 2006), esp. 13-84; Melissa Calaresu, "Looking for Virgil's Tomb: the End of the Grand Tour and the Cosmopolitan Ideal in Europe", in J. Elsner and J. P. Rubies, eds., Voyages and Visions: Towards a Cultural Theory of Travel (London, 1999), 138-60. 
Kingdom 'of the Two Sicilies, while this exotic sense of voluptuous ease became one of the great attractions to the traveler. As Chard puts it, "southern languor and 'mollesse' [lifelessness] are viewed as promoting a capacity for pleasure that is worthy of investigation and even perhaps of imitation".48 Expressions of sensual languor-viewed, it is true, with some ambiguity — can be found in many of the commentators in the third quarter of the eighteenth century, including, most famously, Johann Wolfgang von Goethe. Yet the obverse of this attraction was the enduring assumption that the south was irredeemably trapped in a state of backwardness, bereft of industry, initiative and intelligence.

Moore's position is altogether different. True, he is not entirely immune from the suggestion that climate has a role to play, but he is also repeatedly insistent that political arrangements-forms of regime-are the crucial variable. Thus in his discussion of the economic decline of Ferrara, he emphasizes that the only change in the city's environment has been a political one-all the other resources, he emphasizes, remain the same. ${ }^{49}$ When discussing the Neapolitan lazzaroni, dismissed by most visitors as idle, Moore comments,

the lazzaroni are generally represented as a lazy, licentious and turbulent set of people; what I have observed gives me a very different idea of their character. Their idleness is evidently the effect of necessity, not of choice; they are always ready to perform any work, however laborious, for a very reasonable gratification. It must proceed from a fault of Government, when such a number of stout active citizens remain unemployed; and so far are they from being licentious and turbulent, that I cannot help thinking they are by much too tame and submissive. ${ }^{50}$

After commenting on some of the mechanisms used by the nobility and the Church to secure popular obedience, he goes so far as to suggest that the common people have a right of resistance that they would be fully entitled to exercise. ${ }^{51}$

In discussing the common assertion - also to be found among the ancientsthat the southern climate means that "a woman who came hither as chaste as Penelope ... would depart as licentious and depraved as Helen" (a view that even Hume seems inclined to endorse), Moore dismisses such claims, in part because of his own observations, but chiefly because "I have no faith in the sudden operation of physical causes in matters of this kind".52 And when he later asks the question, "Why are the inhabitants of the rich plains of Lombardy, where

\footnotetext{
48 Chard, Pleasure and Guilt, 218.

$49 V S M I, 1: 287$.

50 Ibid., 2: 164. Cf. ibid., 130, 163.

51 Melissa Calaresu draws attention to this point in "From the Street to Stereotype: Urban Space, Travel and the Picturesque in late Eighteenth-Century Naples", Italian Studies, 62 (2007), 189-203, 199-200. 
nature pours forth her gifts in such profusion, less opulent than those of the mountains of Switzerland?" Moore replies,

Freedom whose influence is more benign than sunshine and zephyrs, who covers the rugged rock with soil, drains the sickly swamp, and clothes the brown heath in verdure; who dresses the labourer's face with smiles, and makes him behold his increasing family with delight and exultation; Freedom has abandoned the fertile fields of Lombardy, and dwells among the Mountains of Switzerland. ${ }^{53}$

Moore's explanation of national and group character is analytical, political, social and historical. But the question of understanding "the other", the alien and the foreign is not simply, for Moore, an intellectual matter; it is also a question of sympathy and feeling, of engaging emotionally with the other, of being willing to put yourself in their place, and imagine their way of seeing the world. The first move towards achieving this is overriding an understandable attachment to your own way of doing things. "The not making a proper allowance for the different modes and usages which accident has established", writes Moore, "is one great cause of the unfavourable and harsh sentiments, which the people of the different countries of the world too often harbour against each another". ${ }^{4}$ Difficulties arise when the traveler, confronted by unfamiliar customs, thoughtlessly rejects them as foolish or pernicious. "Travelers are too apt", complained Moore,

to form hasty, and for the most part, unfavourable opinions of national characters. Finding the customs and sentiments of the inhabitants of the foreign countries through which they pass, very different from their own, they are ready to consider them as erroneous, and conclude, that those who act and think in a manner so opposite to themselves, must either be knaves, fools, or both. 55

Difference is constituted as wickedness or folly.

But, taking such a position merely opens up even greater distance between the traveler and the native, so that if the traveler is to learn from his experiences he has to overcome his prejudices. Then, as Moore explains when enumerating the purposes of travel,

However persuaded he [the traveler] may be of the advantages enjoyed by the people of England, he will see the harshness and impropriety of insulting the natives of other countries with an ostentatious enumeration of those advantages; he will perceive how odious those travelers make themselves, who laugh at the religion, ridicule the customs, and insult the police of the countries through which they pass, and who never fail to insinuate to the inhabitants that they are all slaves and bigots. ${ }^{56}$

\footnotetext{
53 Ibid., 2: 449-50.

$54 \quad V S M F, 1: 70-71$.

$55 \quad$ VSMI, 1: 459.

56 Ibid., 2: 496.
} 
Moore does not rely on what Chard in her study of Grand Tour literature identifies as the trope of opposition ${ }^{57}$-an overriding and constantly invoked contrast between (a better) home and an (exotic but inferior) away-but engages in a larger comparative enterprise: "By comparing the various customs and usages, and hearing the received opinions in different countries", he writes of the observant tourist, "his mind will be enlarged." "58 This is a form of understanding that can be applied to all cultures. Thus Moore yields to no one in his regard for many aspects of classical antiquity, but rejects a credulous and uncritical admiration of Rome, and the view of Roman history as a collection of timeless exemplars. He takes it as his task to explain the specific manners and mores of Rome, notably a propensity to cruelty, as in his (accurate) account of the history of gladiatorial games and the arena. ${ }^{59}$ Cultures, classical and modern, are subject to the same critical evaluation, based on an analysis of politics and the economy.

What Moore seeks is the larger object of the understanding of human nature in all its variety, based on a universal capacity for "sympathy". He goes out of his way, in the manner of Hutcheson and Hume, to rebut arguments that seek to reduce acts of kindness to (natural) self-interest. For Moore a man of feeling is a better person. Thus his positive picture of Voltaire largely depends on his portrayal of him as a man of exceptional sympathy, capable of torrents of tears in the playhouse.$^{60} \mathrm{He}$ frequently alludes to and praises acts of sympathy and benevolence. A long account of the charity offered by a French aristocrat to a soldier who has lost his leg and to his ever-loving and beautiful wife (an episode that, more than any other, smacks of Sterne), ends with a paean to impulsive and instinctive benevolence, when compared with calculated charity. ${ }^{61}$ One of Moore's chief arguments against the privileges of aristocracy is that the gilded status of young nobles inhibits their capacity for feeling, for they have never experienced misfortune and suffering. ${ }^{62}$ When in Berne he criticizes the practice of requiring criminals to clean the streets while wearing collars, because he fears that such a public spectacle hardens the hearts of spectators and makes them less compassionate and sympathetic. ${ }^{63}$ In Geneva he is overcome with sympathy for the families of the republic's militiamen:

Even a stranger of a moderate share of sensibility, who recollects the connection between the troops and the beholders [i.e. Genevan families], who observes the anxiety, the

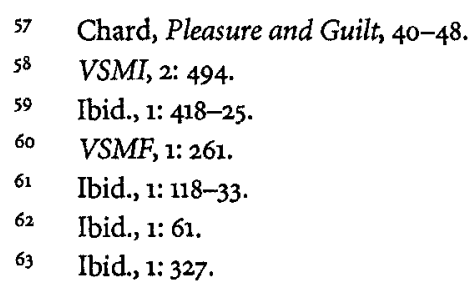


tenderness, the exultation, and the various movements of the heart, which appear in the countenances of the spectators, will find it difficult to remain unconcerned: But sympathizing with all around him, he will naturally yield to the pleasing emotions, and at length behold the militia of Geneva with the eyes of a citizen of the Republic. ${ }^{64}$

The traveler, albeit in what he regards as a highly desirable situation, actually immerses himself in the other.

Of course, Moore was well aware that there were many circumstances that he and many others would regard with disapproval. His injunction to sympathy went hand in hand with a strong prescriptive critique of any form of arbitrary power (which Moore as a good Whig knew would inevitably be abused), of secrecy and lack of transparency (his chief complaint about the republic of Venice), of bigotry and superstition, and of any impediment to the free circulation of ideas and trade. (One of his most lyrical passages on Italy is his account of the wonders of Ancona as a free port. $)^{65}$ But, as his deliberate avoidance of shrill denunciation and jingoistic rhetoric makes clear, his purpose was not to promote a sententious, one-dimensional condemnation of the other, but to engage with those who did not share his views in order to achieve greater understanding. Thus, when in Rome, he shows great compassion for the Duke of Albany, as he calls the Young Pretender, while making clear that he admires the men who removed the Stuarts and secured the Hanoverian succession. ${ }^{66}$

For Moore the object of travel is "the care of forming the heart by the principles of benevolence and integrity". 67 The means of ensuring this is through familiar conversation with the people the traveler meets-not just famous figures such as Voltaire and Frederick the Great but the humble soldier and peasant-and by developing a mutual goodwill; sociability is the key: "By being received with hospitality, conversing familiarly, and living in the reciprocal exchange of good offices with those whom he considered as enemies, or in some unfavourable point of view", he argues, "the sphere of his benevolence and good will to his brethren of mankind will enlarge." 68 Such conduct will also enable the traveler to perceive how things are, producing new knowledge that will enhance his understanding. For example, at first Moore condemns service in the Prussian army as a form of slavery, but after a long debate with a Prussian officer, he concludes that the force is more like a standing militia. ${ }^{69}$ Moore is constantly concerned to make distinctions, to introduce elements of social and cultural complexity into the

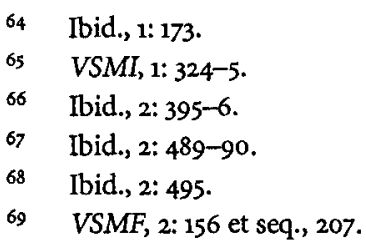


traveler's vision. Thus, in his view, a discerning traveler distinguishes between the politically and historically determined circumstances in which people find themselves, and forms of individual conduct. When someone, he writes, "sees many individuals preserve personal dignity in spite of arbitrary government, and independent mind amidst poverty, liberal and philosophical sentiments amidst bigotry and superstition", he should inevitably hold them "in high esteem", for what they accomplish is much greater than the expression of those same qualities in a free state like Britain..$^{\circ}$

One way to think of Moore's View is to see it as a contribution to the debate among Scottish philosophers, historians and political economists about the question of human attachment, to the problem that Hutcheson, Kames, Smith and Hume posed of how bonds of human sympathy could or might work beyond the immediate confines of the family and the nation..$^{71}$ It is difficult to be precise about Moore's views on this subject. He does not speak, like his mentor, Hutcheson, of a "universal benevolence", and he exhibits, like Smith, Hume and Kames, considerable skepticism about our ability to sympathize beyond our immediate kin. At one point, defending artificial politeness against its critics, he remarks,

If writers or preachers of morality could, by force of eloquence, eradicate selfishness from the hearts of men, and make them in reality love their neighbours as themselves, it would be a change devoutly to be wished. But until that blessed event, let us not find fault with those forms of attention which create a kind of artificial friendship and benevolence, which for many of the purposes of society produce the same effects as the true. ${ }^{72}$

But like Hutcheson, he seems to think that there are ways in which a more open sympathy can be nurtured by a variety of means, some of which can and should be part of foreign travel. Perhaps these can best be parsed out by returning to Mark Phillips's varieties of historical distance. We are here concerned, of course, with a work of travel and geography, but there is no reason why the forms of distancingwhat Phillips describes as "formal, affective, ideological and conceptual"—should not be applied to Moore's text. We have already seen that Moore's style was praised for its informality, and have seen that he interspersed passages of reported speech and accounts of his conversations in order to pull his readers into the text, conveying a sense of what Kames called "ideal presence".?3 Much of the View is not seen from afar. At the same time, Moore's tone combines utile e dulce.

$70 \quad$ VSMI, 2: 497.

71 For a general discussion of this issue see Evan Radcliffe, "Revolutionary Writing, Moral Philosophy, and Universal Benevolence in the Eighteenth Century", Journal of the History of Ideas, 54, 2 (April 1993), 221-40.

72 VSMF, 1: 84-5.

73 Henry Home, Lord Kames, Elements of Criticism, 2 vols (Edinburgh, 1765), 1: 95-6. 
He sweetens the reader with his comedy of manners-his tales on the roadbut skillfully distances himself from the chauvinistic traveler by tempering his criticisms of foreign manners and institutions with a "cool" irony. He is not averse to playing some Shandean games-it was hard for travel writers to avoid them in the aftermath of Sentimental Journey, and can paint the pathetic - as in the tale of the mutilated French soldier and his beautiful young wife-exciting the sympathy of his readers. Yet his conclusions from such stories are never whimsical, like many of Sterne's, but seek to make a general point about the workings of human nature. For Moore has a very clear ideological end-to increase both human benevolence and understanding - which makes his framing of closeness and distance both complex and interesting. On the one hand he is insistent upon a closeness on the part of a traveler that is tantamount to immersion. The traveler must not just look and observe from afar, he must speak, engage, learn, argue; he must live "in the reciprocal exchange of good offices" with the foreigner he meets. ${ }^{74}$ This is a brave recommendation in the light of repeated fears of the corruption and cooptation of the traveler, voiced in most travel literature on the Grand Tour, and echoed in the anxieties often expressed in parental correspondence. But this intimate engagement with the foreign is only valuable when combined with a certain distancing, stepping back from immediate experience to consider how and why it has assumed the form it does. Such moments of reflection, informed by an analysis of the complex factors that make up the manners and customs of different societies, polities and persons, not only enable the traveler to understand what he experiences, but also help demystify the unfamiliar and strange, bring it closer, and therefore remove the barriers to sympathy and understanding. The process creates a virtuous circle that, once entered, can only be reinforcing. A cognitive procedure nurtures an emotional response. Paradoxically, intellectual distance creates the feeling of sympathy, "forming the heart by the principles of benevolence and integrity"75

See n. 68 above.

VSMI, 2: 489 . 